\section{References}

Bross, I. D. J., Rimm, A. A., Slack, N. H., Ausman, R. K., and Jones, R. (1966a). Cancer, 19, 1780

Bross, I. D. J., Rimm, A. A., Slack, N. H., Ausman, R. K., and Jones, R. (1966b). Cancer, 19, 1785.

Denk, W., and Karrer, K. (1961). Cancer, 4, 1197.

Galton, D. A. G. (1953). Lancet, 1, 208.

Higgins, G. A., Serlin, O., Hughes, F., and Dwight, R. W. (1962). Cancer Chemotherapy Reports, No. 16, 141 .,

Horwitz, H., Wright, T. L., Perry, H., and Barrett, C. M. (1965). American fournal of Roentgenology, Radium Therapy, and Nuclear Medicine, 93, 615.

Hughes, F. A., and Higgins, G. (1962). fournal of Thoracic and Cardiovascular Surgery, 44, 295.

Karrer, K. (1965). Wiener klinische Wochenschrift, 77, 383.

Karrer, K. (1967). Münchener medizinische Wochenschrift, 109, 1320.
Karrer, K. (1970). "The Importance of Dose-Schedules in Adjuvan t Chemotherapy," paper read at 10th International Cancer Congress, Houston, Texas, May, 1970.

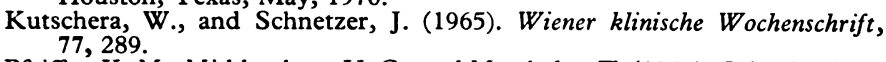

Pfeiffer, K. M., Middendorp, U. G., and Marthaler, T. (1966). Schweizerische medizinische Wochenschrift, 96, 908.

Poulsen, O. (1962). Fournal of the International College of Surgeons, 37, 177. Poulsen, O. (1963). Acta Chirurgica Scandinavica, 125, 498.

Poulsen, O. (1965). Acta Chirurgica Scandinavica, Suppl. No. 332, p. 138. Sullivan, R. D. (1958). Annals of the New York Academy of Sciences, 68, 1039.

Veternas Administration Adjuvant Cancer Chemotherapy Cooperative Group (1961). Archives of Surgery, 82, 466.

Weatherall, D. J., Galton, D. A. G., and Kay, H. E. M. (1969). British Medical fournal, 1, 638.

\title{
Serum Transaminases during Salicylate Therapy
}

\author{
A. S. RUSSELL., R. A. STURGE, M. A. SMITH
}

British Medical fournal, 1971, 2, 428-429

\section{Summary}

In 8 out of 32 juvenile patients suffering from chronic polyarthritis and in one patient with dermatomyositis, raised transaminase levels were found; the salicylate level was above $35 \mathrm{mg} / 100 \mathrm{ml}$ in all except one. Reduction in the salicylate level led to a prompt fall in the serum transaminases. Despite a rise in alkaline phosphatase in three cases there was no other evidence of liver dysfunction in the children. Only one of the adults showed a rise in transaminase levels, and she had mild cirrhosis.

\section{Introduction}

Our attention was drawn to the association of increased levels of serum transaminases with high serum salicylate levels in a girl with juvenile chronic polyarthritis admitted routinely for establishment on a salicylate regimen. She complained of feeling unwell and was found to have mild hepatomegaly and raised transaminase levels; at this time her serum salicylate level had risen to $45 \mathrm{mg} / 100 \mathrm{ml}$. On stopping aspirin therapy the transaminase levels rapidly returned to normal and the hepatomegaly disappeared. In view of this 50 further patients were studied.

\section{Patients and Methods}

Of the 50 patients 32 were children aged 2 to 15 years and 18 were adults aged 29 to 68 . There were six males among the children and five among the adults. All were inpatients at the time, and apart from one child with dermatomyositis all had juvenile chronic polyarthritis or definite rheumatoid arthritis.

M.R.C. Rheumatism Research Unit, Canadian Red Cross Memorial Hospital, Taplow, Maidenhead, Berks

A. S. RUSSELL, M.R.C.P., Registrar (Present address: West London

R. A. STURGE, M.B., B.S., Registrar (Present address: St. Stcphen's Hospital, London S.W.10)

M. A. SMITH, M.SC., Department of Biochemistry
Salicylates were being administered as part of their therapeutic regimen either in the form of Enseal aspirin or Disprin. None of the patients were taking ibuprofen but some were receiving prednisone.

On the same sample of blood the salicylate levels were assayed by the method of Trinder (1954) and transaminase levels by that of Reitman and Frankel. The levels accepted here as normal are serum aspartate aminotransferase (SGOT) 8-40 units, serum alanine aminotransferase (SGPT) 5-35 units. The alkaline phosphatase was measured in King-Armstrong units, the normal range being 5-12 units in adults; however, a level of up to 20 units in a growing child was not considered necessarily abnormal.

\section{Results}

Raised transaminase levels were seen in nine children and one adult (Tables I and II). All but one of the children with

TABLE I-Results in 33 Children and 18 Adults

\begin{tabular}{lc|c|c|c|c}
\hline Children & $\left\{\begin{array}{c}\text { Salicylate } \\
\text { Level } \\
(\mathrm{mg} / 100 \mathrm{ml})\end{array}\right.$ & $\begin{array}{c}\text { No. of } \\
\text { Patients }\end{array}$ & $\begin{array}{c}\text { No. with Raised } \\
\text { Transaminase } \\
\text { Level }\end{array}$ & $\begin{array}{c}\text { No. with Raised } \\
\text { Alkaline } \\
\text { Phosphatase }\end{array}$ \\
\hline$>35$ & 14 & 8 & $2 / 6$ \\
& $\{35$ & 19 & 1 & $* 2 / 11$ \\
$>35$ & 3 & 1 & $1 / 1$ \\
& $\{35$ & 15 & 0 & $0 / 8$
\end{tabular}

*In une case associated with increascd transaminasc levels.

TABLE II-Maximum Lecels of Transaminascs Sicn in the Nine Children and Onc Adult with Raiscd Liciols

\begin{tabular}{|c|c|c|c|c|c|}
\hline SGOT & SGPT & SGOT & SGPT & SGOT & SGPT \\
\hline \multicolumn{6}{|c|}{ Children } \\
\hline 99 & 79 & 840 & 2,000 & 66 & 84 \\
\hline 48 & 35 & 150 & 200 & & 105 \\
\hline 530 & 200 & 65 & 53 & $>150$ & $>150^{*}$ \\
\hline \multicolumn{6}{|c|}{ Adult } \\
\hline$>150$ & $>150$ & & & & \\
\hline
\end{tabular}

*Patient referred to in the Chart.

raised transaminase levels had a serum salicylate of over $35 \mathrm{mg} / 100 \mathrm{ml}$ (equivalent to $2.5 \mathrm{mmol}$ salicylates). None of the children had nausea, sweating, or hyperventilation to suggest salicylate toxicity. One child with a mildly raised 
transaminase level and a salicylate level of only $27 \mathrm{mg} / 100 \mathrm{ml}$ had much higher readings at a later date, when the salicylate level had risen to $39 \mathrm{mg} / 100 \mathrm{ml}$ (see Chart). In spite of a con-
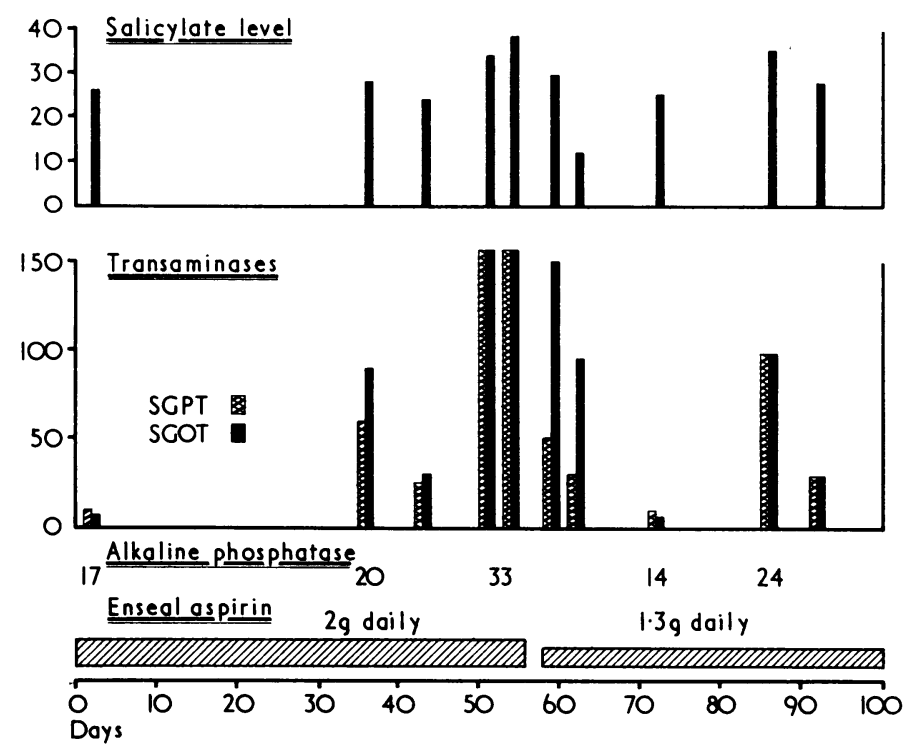

Salicylate, transaminases, and alkaline phosphatase levels in a child aged 8 years who had had Still's disease for five years.

stant dose of Enseal aspirin the serum salicylate levels varied widely in this patient, presumably owing to irregular absorption of the coated aspirin. The raised transaminases occurred when the salicylate levels were at their highest. The transaminase rises varied widely and did not correlate directly with the salicylate levels or with rises in the alkaline phosphatase. In all the patients the raised transaminase levels fell to normal, usually within one week, when the salicylates were discontinued, and it was possible to recommence the drug, provided the dose was reduced, without another' rise in transaminases.

Two of the children with raised transaminases and high salicylate levels had more detailed liver function tests as they both had a raised alkaline phosphatase. The 5-nucleotidase was raised but the bromsulphthalein excretion test was normal. The one adult patient with a raised transaminase level (Table I) was known to have mild hepatic disease with a raised alkaline phosphatase level and an abnormal bromsulphthalein retention (19\% at 45 minutes); in this case a liver biopsy specimen showed mild cirrhosis. Nevertheless, the raised transaminase levels fell to normal on cessation of salicylate therapy. There was no apparent effect of prednisone on these levels as there were equal numbers receiving it in both groups.

To ensure that these results were not due to salicylates interfering with the transaminase assay, Disprin was dissolved

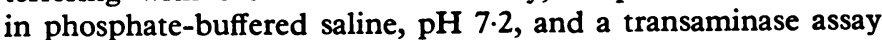
performed on the solution. Disprin was also dissolved direct in serum specimens with both normal and raised transaminase levels; in no case was any interference with the assay found. This was also true when sodium salicylate was used.

\section{Discussion}

Manso, Taranta, and Nydick (1956) examined the relation between salicylates and transaminases in children with rheumatic fever. They noted that administration of salicylate in a dose of $0.6-1 \mathrm{~g} / 15 \mathrm{lb}(90-145 \mathrm{mg} / \mathrm{kg})$ body weight daily for 10 days could induce an increased transaminase level in 7 out of 14 children. They also noted that normal adults given up to $6 \mathrm{~g} /$ day for one week did not develop raised transaminase levels. Our findings are similar to these. Wilkinson (1962) stated that salicylates may give rise to toxic symptoms with nausea, vomiting, and hyperventilation, with a gradual increase in transaminases. However, no source was quoted in the review for this observation. None of our young patients had symptoms or signs of salicylism.

Salicylates and transaminases do interact in vitro, but salicylates diminish the activity of the transaminase enzymes rather than increase it (Gould, Dawkins, Smith, and Lawrence, 1966) and, moreover, concentrations of about $10 \mathrm{mmol}(140$ $\mathrm{mg} / 100 \mathrm{ml}$ ) are required to produce this effect. Janota, Wincey, Sandford, and Smith (1960) showed that rabbits given salicylates develop increased serum levels of a variety of liver enzymes, including SGOT, SGPT, aldolase, and lactic dehydrogenase. This rise was not seen until the drug had been administered for about two weeks, and some of the eight animals used needed a serum salicylate level of $75 \mathrm{mg} / 100 \mathrm{ml}$ to achieve this. The liver biopsy specimens in two out of six examinations showed fatty infiltration.

The importance of this effect of salicylate therapy lies chiefly in its recognition as such. Recently we had an additional patient with rheumatic fever referred to the unit who was being treated with aspirin and whose raised transaminase levels had proved confusing to the referring hospital; these returned to normal on stopping aspirin. Only one of our juvenile cases with raised transaminase levels showed any pronounced degree of hepatomegaly; it was also present in one other case at a time when the transaminase levels were normal. Our cases did not resemble those described by Schaller, Beckwith, and Wedgewood (1970), who reported five cases, four being boys, with pronounced systemic manifestations of juvenile rheumatoid arthritis and massive hepatomegaly. Four of these patients had raised serum transaminases. The therapy before admission was not known for certain, and the authors commented that "all had probably received salicylates sporadically because of fever." Histological examination in four of the cases, however, showed some periportal mononuclear infiltration but no great distortion of liver architecture or cell necrosis. Though this seems to have been part of the systemic manifestation of their Still's disease the derangement in liver function might reflect previous therapy.

\section{References}

Gould, B. J., Dawkins, P. D., Smith, M. J. H., and Lawrence, A. J. (1966). Molecular Pharmacology, 2, 526.

Janota, I., Wincey, C. W., Sandford, M., and Smith, M. J. H. (1960) Nature, 185, 935.

Manso, C., Taranta, A., and Nydick, I. (1956). Procecdings of the Society for Experimental Biology and Medicine, 93, 84.

Schaller, J., Beckwith, B., and Wedgewood, R. J. (1970). Fournal of Pediatrics, $77,203$.

Trinder, P. (1954). Biochemical fournal, 57, 301.

Wilkinson, J. H. (1962). An Introduction to Diagnostic Enzymology, p. 131. London, Arnold. 